\title{
Corporate Social Responsibility in Nepalese Commercial Bank with reference to Bank of Kathmandu Limited
}

\author{
Laxman Raj Kandel \\ Lecturer, Nepal Commerce Campus
}

\begin{abstract}
Corporate social responsibility (CSR) is all about companies managing their business process to produce the overall positive impact on the society. The interest for CSR has grown rapidly the recent years and people started to demand corporate social responsibility from the company. CSR is connected with corporate behaving ethically, morally and socially responsible towards the society. This research focuses on investigating why companies engage in CSR, how they apply CSR and how CSR can affect financial performance. It was found that the employees and the people in general do get motivated by their organization. All the respondents were very positive and energized about being part of the CSR activities provided with the opportunities. BOK Ltd has focused their CSR activities related with the health, education and environment with the name as BOK health, BOK education and BOK environment initiation. BOK has tried to cover the different aspect of essential factors in anyone's life. Majority of the respondents' views that CSR activities has the positive relation and can contribute on the financial performance of the company as it increases the good image and goodwill of the organization. CSR needs planning and proper implementation so that the society could actually have positive impact from CSR activities. In Nepalese context the organization do not emphasize in CSR activities rather they give priorities to earn more profit and flourish their business.
\end{abstract}

Key words: Corporate social responsibilities, employees, performance, philanthropic, environment, respondents

\section{INTRODUCTION}

\subsection{Background of the study}

Corporate Social Responsibility (CSR) is also called Corporate Conscience, Corporate Citizenship, Social Performance, or Sustainable Responsible Business/ Responsible Business.CSR is as form of corporate self-regulation integrated into business 
model. CSR is a process with the aim to embrace responsibility for the company' action and encourage a positive impact through its activities on the environment, consumers employees, community's stakeholders and all other members of the public sphere who may also be considered as stakeholders.

Further, we should not end up in a situation where the imperatives of 21st century force corporations to change their behavior. Instead, a voluntary mindset is something that is better suited given the vast resource that corporations have and which they deploy to resist change and thwart those push for legislation that aims to do so.

\subsection{CSR and business efficiency}

The six criteria discussed by Young and Tilley are eco-efficiency, socio-efficiency eco-effectiveness, socio-effectiveness and sufficiency and ecological equity. Taken together as a whole, these six criteria form an integrated model which corporations can follow for sustainable business practices and reap profiles as well as be conscious in their business practices. The point here is that the motto that CSR pays in real economic terms ought to be broadcast far and wide and only when corporations realize the economic benefits of conscious capitalism would they embrace the paradigm of CSR wholeheartedly(Young and Tilley,2006).

This has led to the mainstreaming of the idea of CSR to the extent that we have reached a point in the west where CSR is a business imperative in the same way taking care of the workplace is.

However, in recent decades, countries like India Brazil have indeed take the lead in making businesses adopt policies that are socially responsible, environmentally conscious, compassionate in their human dimensions and thrifty in their use of natural resources.

\subsection{Statement of the problem}

CSR is an accepted and effective concept for business to help solve societal problems and at the same time strengthen their core business activities. CSR is an important tool in increasing the goodwill of the company andeventually achieving profits to the company. This research mainly try to solve the following questions.

- Do the employees get motivated and could associate themselves proudly with their company' CSR activities?

- $\quad$ Are the CSR activities actually beneficial to the society?

- Can the CSR contribute in the financial performance of the company?

\subsection{Objectives of the study}

The major objectives is to find out whether the commercial banks perform the CSR activities as per their capability and with integrity or not. The specific objective is to:

- $\quad$ Assess the CSR activities carried out by BOK.

- Analyze the impact of CSR activities on organization in its overall business. 
- Provide suggestion and recommendation to the organization for the further improvement of their CSR endeavor.

\section{LITERATURE REVIEW}

\subsection{Conceptual review}

Corporate Social Responsibility (CSR) is the continuing obligation of a business to behave ethically and contribute to the economic development of the organization. It improves the quality of life of the organization. The meaning of CSR has two folds. On one hand, it exhibits the ethical behavior that an organization behaves towards its internal and external stakeholders. And on the other hand, it denotes the responsibility of an organization towards the environment and society in which it operates. Thus CSR makes a significant contribution towards sustainability and competitiveness of the organization and competitiveness of the organization.(Chapagain, B.R., 2010:21)

In recent years, CSR or Corporate Social Responsibility has become the latest buzzword among the companies. This refers to the practice of the corporate in "giving back" to society in the form of programs that benefit the less privileged members of the society. They can take form of outreach programs that adopt schools; communities etc and provide funds for their upkeep as well as promote socially conscious business practices that lead to the betterment of society (Caroll,1999).

\subsection{CSR and its relation to sustainable development}

Using CSR as one of the tools to attain sustainable development is not enough if the formulation and implementation of the policies does not involve the recipients of such developments. Although governments, especially in developing countries, continue to play a major role in addressing the development needs of their citizens, "the promotion of social development issues must also be one of partnership between government and private and non-governmental actors and, in particular, the corporate sector" (Hopkins, 2004).

The demand for companies that invest in CSR has increased in recent year from: Customers; employees, suppliers, community groups, governments as well as some shareholders. As the concern for global warming has increased rapidly the past years this has led to a further increase in demand for CSR (Diana, 2006). Several companies have responded by increasing their CSR investments (Mc Williams \& Siegel, 2000). Due to this there are an increasing number of companies continuously working with CSR related issues. However, other companies have resisted investing in CRS as they believe that it contradicts their aim to maximize profits (Mc Williams \& Siegel, 2000).

\subsection{Research gap}

Various researches have been conducted under CSR in the international arena. However, CSR related research in the Nepalese context that too associated with Nepalese commercial banks were difficult to be found.The international thesis works on CSR will be an example and an eye opener to the businesses houses all around the globe. It is because that the research work have been successfully focusing on the

$$
\sim 92 \sim
$$


demand and need of doing something in return to the society by firms/organizations. Business with ethics and conscience have been performing the CSR activities on their capability and have even benefited from the corporate good image which in turn helps in the success of the core business operation.

\section{RESEARCHMETHODOLOGY}

\subsection{Research Design}

This study is exploratory and descriptive as well in nature. Exploratory in the sense, the major emphasis in my thesis work is in the discovery of ideas and insights regarding CSR descriptive in the sense.

\subsection{Population and sampling procedures}

There are 28 commercial banks functioning all over the country and most of them have initiated the CSR activities as per their knowledge, conscience and capability and here, BOK Ltd is taken for the case study. The bank has performed various CSR related activities and contributed to its stakeholders like other related banks. Thus, the date from 2013 A.D to 2017A.D. are studied and analyzed for the fulfillment of the objective.

\subsection{Sources of Data}

The sources of data are both primary sources and secondary. The primary data includes questionnaires distributed and collected from the employees of BOK Ltd at Gyaneshwor, Baneshwor and NewRoad Branch. The sample unit selected for the primary data are 120 respondents from different level.

\section{DATA PRESENTATION AND ANALYSIS}

In the data analysis part the collected data through primary sources of data have been represented in the suitable formats (i.e. on tables and charts), and are being analyzed. Certain inferences and interpretation have also been made finally.

\subsection{Distribution of data as per demographic factor}

Table 1. Distribution of data as per demographic factor

\begin{tabular}{lcc}
\hline & No. of Respondent & Percentage \\
\hline Male & Gender & \\
\hline Female & 60 & $50 \%$ \\
\hline Total: & 60 & $50 \%$ \\
\hline & 120 & $100 \%$ \\
\hline Married & Marital Status & $30 \%$ \\
\hline Unmarried & 12 & $70 \%$ \\
\hline Total: & 108 & $100 \%$ \\
\hline
\end{tabular}




\begin{tabular}{|c|c|c|}
\hline & No. of Respondent & Percentage \\
\hline \multicolumn{3}{|c|}{ Age } \\
\hline $20-30$ & 100 & $95 \%$ \\
\hline $30-40$ & 20 & $5 \%$ \\
\hline $40-50$ & 0 & 0 \\
\hline Above 0 & 0 & 0 \\
\hline Total: & 120 & $100 \%$ \\
\hline \multicolumn{3}{|c|}{ Education Levels } \\
\hline \multicolumn{3}{|l|}{ Intermediate } \\
\hline Bachelors & 48 & $40 \%$ \\
\hline Masters & 72 & $60 \%$ \\
\hline Others & 0 & 0 \\
\hline Total & 120 & $100 \%$ \\
\hline \multicolumn{3}{|c|}{ Title of Post } \\
\hline Managerial Level & 20 & $5 \%$ \\
\hline Non Managerial Level & 100 & $95 \%$ \\
\hline Total & 120 & $100 \%$ \\
\hline \multicolumn{3}{|c|}{ Years of Experience } \\
\hline $0-5$ & 112 & $80 \%$ \\
\hline $5-10$ & 8 & $20 \%$ \\
\hline $10-15$ & 0 & 0 \\
\hline 15 Above & 0 & 0 \\
\hline Total & 120 & $100 \%$ \\
\hline
\end{tabular}

\subsection{Impact on employees' motivation in relation with company's CSR} Table 2:Impact on employees' motivation in relation with company's CSR

\begin{tabular}{ccc}
\hline Responses & No. of Participants & Percentage \\
\hline Satisfied & 4 & $3.33 \%$ \\
\hline Motivated & 96 & $80 \%$ \\
\hline Neutral & 20 & $16.67 \%$ \\
\hline Total & 120 & $100 \%$ \\
\hline
\end{tabular}

Source: Source: Field survey, 2017

From the table 2 it is foundthat $80 \%$ of the employees feel positively motivated in being part of the CSR activities directly or indirectly. $3.33 \%$ of the employees felt satisfied and happy with the CSR activities of their company. While $16.67 \%$ of the employees neither felt satisfied nor were motivated to perform more CSR activities. This shows that employees or let's say people in general get motivated with the CSR activities. 
4.3 Relation of CSR with the financial performance of the company

Table 3: Relation of CSR with the financial performance of the company

\begin{tabular}{ccc}
\hline Responses & No. of respondent & Percentage \\
\hline Positive & 112 & $93.33 \%$ \\
\hline Negative & 0 & 0 \\
\hline Indifferent & 8 & $6.67 \%$ \\
\hline Total & 120 & $100 \%$ \\
\hline
\end{tabular}

Source: Source: Field survey, 2017

As per the table we can clearly see most of the respondents believe that there is positive relation of CSR with the financial performance of the company. $93.33 \%$ of the respondent said that the CSR can in return have the good impact on the financial or in the core business of the company. However, $6.67 \%$ of the respondents were neutral or indifferent regarding the thoughts about the impact on the financial performance of the company.This shows that majority of people believe in the fact that CSR contributes in the financial performance of the company.

\subsection{Impact of CSR on company's goodwill /image}

Table 4: Impact of CSR on company's goodwill /image

\begin{tabular}{ccc}
\hline Responses & No. of respondent & Percentage \\
\hline Positive & 116 & $96.67 \%$ \\
\hline Negative & 0 & 0 \\
\hline None & 4 & $3.33 \%$ \\
\hline Total & 120 & $100 \%$
\end{tabular}

Source: Source: Field survey, 2017

The table above shows that the most of the respondents believe that the CSR activities positively contribute on the company's goodwill/ image. $96.67 \%$ of the respondents were of the thoughts that with the increase CSR activities company can definitely bring good image and goodwill to its company for the long run term which would be beneficial to the company in some way or the other. However, $3.33 \%$ of the respondents were indifferent on this matter. This shows that there is positive impact with the CSR activities on the company's goodwill.

\subsection{Objective of CSR}

Table 5: Objective of CSR

\begin{tabular}{ccc}
\hline Responses & No. of respondent & Percentage \\
\hline Philanthropic nature & 24 & $20 \%$ \\
\hline Sustainable development & 40 & $33.33 \%$ \\
\hline Social awareness & 56 & $46.67 \%$ \\
\hline Total & 120 & $100 \%$ \\
\hline & $\sim 95 \sim$
\end{tabular}




\section{Source: Source: Field survey, 2017}

As per table we can conclude that the employees consider CSR's activities more as the social awareness, sustainable development and finally as the philanthropic act. In the pie chart the respondent's views have been divided on the objective of the CSR activities. About 20\% of the respondents believed that the objective of CSR can be associated with the philanthropic nature. Nearly $33.33 \%$ of the respondents believed that the objective of theCSR activities must be concerned with the sustainable development issues. This shows that the main objective of CSR in the eye of the people in large is associated with creating awareness in the society as a whole.

\subsection{Focus of CSR activities}

Table 6: Focus of CSR activities

\begin{tabular}{ccc}
\hline Responses & No.of respondent & Percentage \\
\hline Education & 72 & $60 \%$ \\
\hline Health & 32 & $26.67 \%$ \\
\hline Environment & 16 & $13.33 \%$ \\
\hline Total & 120 & $100 \%$ \\
\hline
\end{tabular}

Source: Source: Field survey, 2017

As per the table it can be concluded that the majority of the respondents advocate that the focus of the CSR activities must be on the education aspect of the life. $60 \%$ of the respondents were of the opinion that education matters a lot in today's world so they happen to focus on the education aspect of life about CSR activities. 26.67\% of the respondents believed that the focus of the CSR activities must be shifted to the health aspect of the life. However, $13.33 \%$ of the respondents said that the focus of CSR must be on the environmental aspect as well.This shows that most of the people believe in creating awareness about the education in one's life.

\subsection{Situation of CSR activities in our country as a whole}

Table 8: Situation of CSR activities in our country as a whole

\begin{tabular}{ccc}
\hline Responses & No. of respondent & Percentage \\
\hline Needs to be appreciated & 12 & $10 \%$ \\
\hline Has a long way to go & 72 & $60 \%$ \\
\hline Not up to the standard of international arena & 36 & $30 \%$ \\
\hline Total & 120 & $100 \%$ \\
\hline
\end{tabular}

Source: Source: Field survey, 2017

As per the table we can see the fact that majority of the respondents were of the thoughts that the CSR activities initiated by the companies of our country as a whole has a long way to go. $60 \%$ of the respondents were on the very line. $30 \%$ of the respondents were of the thoughts that the CSR activities of our organizations as a whole still has no meet the standard of the global world. However, $10 \%$ of the respondents believed 
that the CSR activities initiated by the organizations of out county as a whole need to be appreciated. This shows that the CSR activities initiated by the organization of our county has a room for improvement and still has a long way to go.

\subsection{Data analysis of interview}

On the basis of an interview session with Miss Brinda Singh, Officiate- Marketing \& Corporate communication, BOK Ltd revealed that CSR is about organizations behaving ethically and morally right. She further added that CSR is carried out with the purpose of giving back to the society in return to some extent. CSR is about purely working on the betterment and contributing to the society as per the capability of the organization involved. CSR is performed with the view of building company's positive image and thus increasing the goodwill of the company in the market. Regarding the financial relation with CSR activities performed by her institution, she was opined that her institution performs the CSR activities purely on giving back to the society without thinking about it having positive relation with the financial performance or the core business of the institution. She further added that the organization on yearly basis sets aside the budget for the CSR activities and I personally feel this act of BOK Ltd need to be appreciated as this shows the pure intention about contributing the people and the society as a whole by the very institution.

\section{CONCLUSIONS}

CSR is connected with corporate behaving ethically, morally and socially responsible towards the society.

CSR cannot be performed with the small amount of money and with the less time spent for the very activities. It needs planning and proper implementation so that the society could actually have positive impact by the CSR activities.

Corporate social responsibility is not going to solve the world's problem. Still the capable companies can make a difference in life of the people by creating sustainable development opportunity in the society where it operates it business.

Corporate social responsibility (CSR) in context of developing counties including outs is on the preliminary stage of its planning and functioning process. However, today's people are aware of the fact that companies need to perform CSR activities as they gain everything from the society then they ought to give something in return to the society where it operates it business. Our companies or institution cannot spend much time, effort and money on various CSR activities as compared to the largely successful companies.

In a nutshell, CSR is the act of companies behaving ethically or in other words, the business should have ethics and moral being incorporated while doing their business. The definition provided by Mellan Baker (2004), CSR is all about how companies manage the business processes to produce an overall positive impact on society.

\subsection{Discussion}

Corporate social responsibility (CSR) is about the conscience of the companies

$$
\sim 97 \sim
$$


regarding their social responsibility towards the society. However some of the recommendation to the companies of our country as a whole are:

- $\quad$ CSR activities should not be limited only to the philanthropic and creating awareness among the people of the society if possible the CSR activities should focus on creating sustainable development for the people as well as companies performing the CSR activities.

- It is not compulsion for companies to perform CSR activities to contribute society at some way or other. Companies can even perform the greatest CSR activities by doing their business ethically and morally correct. It means that companies can perform CSR act by simply carrying out their business activities a right and proper way.

- For creating and promoting the CSR activities within the companies, the media can play an important role by advocating the need and importance of CSR in today's business world.

- Above all, the government should have some plan in order to encourage companies in performing CSR activities as CSR activities spread the kind help, support, love, peace and brotherhood within the people of the society. And, this way the world definitely would a beautiful place to live in.

\section{Bibliography}

Adamsson, S. \& Johansson, J. (2008) URL: www.diva-portal.org/diva/get documented?Urn_nbn_ se_sh_diva-1457-1-text.pdf, Retrieved-Nov 24, 2016.

Agrawal, G.R. (2013), Strategic management and business environment, Kathmandu: M.K. publication.

Dahal, S. \& Dahal, B. (2002). A handbook of banking, Kathmandu: Asmita Books Publishers \& Distributors.

Kotler, P. \& Lee, N. (2005). Corporate social responsibility: Doing the most Good for your company \&Your case. Hoboken, New Jersey. Jon Wiley \& sons, Inc

Young \& Tilley (2006). Conscious capitalism would they embrace the paradigm of CSR whole heartedly, 411.

Chapagain, B.R. (2010). Corporate social responsibility: Evidence from Nepalese financial service and manufacturing sectors, Journal of Development, 11 (10): 20-21, Patan Multiple Campus.

Caroll, A. B. (1999). Corporate social responsibility, Evaluation of definition construct, business and society, 38 (3): 268-295.

Caroll, A. (1997). A Three-dimensional conceptual model of corporate performance. Academy of Management Review, 4,497-505.

Mcwilliams, A. \& Sigel, D. (2000).Corporate social responsibility and financial performance: Correlation or Misspecification?"- Strategic Management Journal, 21(5): 603-69, retrievedApril,5,2008 from Springer link database.

The Himalayan Times (2012, April). Kathmandu: NMB's bank's social initiative The Republica, Kathmandu: Science lab set up at Kirtipur.

Visser, W. (2008). CS myths popular misconceptions on corporate social sustainability and responsibility. URL: www.waynevisser.com/atricles/csr-myths

Weizel, C. (2006, Nov). CSR in Nepal. 


\section{Websites}

www.pepsico.co.uk/our-company/media-center/news-and-comment/pepsico-uk-partners-with department-of healthe-play4life-campaign.

www.managemntstudyguide.com/cusiness-need-corporate-social-responsibility.htm www.managementstudy guide.com/corporate-social-responsibility-or-profits.htm 